\title{
Analysis of households food insecurity and its coping mechanisms in Western Ethiopia
}

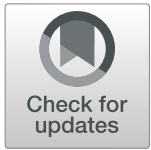

Seid Sani ${ }^{1 *}$ iD and Biruk Kemaw ${ }^{2}$

\author{
* Correspondence: seidsn@gmail. \\ com \\ ${ }^{1}$ Department of Agricultural \\ Economics, College of Agriculture \\ and Natural Resource, Wolkite \\ University, Wolkite, Ethiopia \\ Full list of author information is \\ available at the end of the article
}

\begin{abstract}
This study analyzed households' food insecurity and its determinants along with the coping mechanisms opted against food insecurity and shortage in Assosa zone, western Ethiopia. The study used a primary data collected from 276 randomly selected households for 7 consecutive days from each sample using weighed records method. In addition, focus group discussions and key informants interview were also used. This study employed descriptive statistics, food insecurity index and Tobit model to analyze the data. The finding of the study revealed that, in the study area, the incidence of food insecurity was 53.62\%, with the depth and severity of food insecurity being $16.84 \%$ and $7.32 \%$, respectively. The study finding also pointed out that the mean kilocalorie intake of food insecure households was $1440.37 \mathrm{kcal} / \mathrm{AE} / \mathrm{day}$, with the minimum and maximum being $597.65 \mathrm{kcal}$ and $2048.13 \mathrm{kcal}$, respectively. Furthermore, the estimated Tobit model result revealed that age of the household head, family size and off-farm and non-farm income positively affected extent of households food insecurity; whereas access to irrigation, farm income, distance to market and access to credit negatively affected the extent of households' food insecurity. Moreover, the study also identified that reducing meal size, reducing frequency of meal served, working as a daily laborer and selling livestock's were the top four main coping mechanisms opted against food insecurity and/or shortage. Therefore, to reverse the incidence, future interventions should focus on the aforementioned factors to build the capacity of households through enhancing their access to human, financial and physical capital.
\end{abstract}

Keywords: Food insecurity, Coping mechanism, Tobit model, Assosa zone, Ethiopia

\section{Introduction}

Food is both a basic need and a human right as enough food in terms of quantity and quality for all people is an important factor for a healthy and productive life as well as for a nation to sustain its development (FAO (2014); Sani and Kemaw 2017). Besides, enough food in terms of quantity and quality is a key for maintaining and promoting political stability and insuring peace among people (Idrisa et al. 2008). However, reports indicated that about 1.4 billion poor people were living on less than US\$1.25 a day and 1 billion of them live in rural areas where agriculture is the main source of livelihood, especially in sub-Saharan Africa and Southern Asia (IFAD 2011). Furthermore, FAO (2015) reported that about 795 million people in the world were food insecure, with many more suffering from 'hidden hunger' caused by micronutrient or protein deficiencies. Moreover, different studies depicted that food insecurity occurred in most countries to varying degrees, and

(c) The Author(s). 2019 Open Access This article is distributed under the terms of the Creative Commons Attribution 4.0 International License (http://creativecommons.org/licenses/by/4.0/), which permits unrestricted use, distribution, and reproduction in any medium, provided you give appropriate credit to the original author(s) and the source, provide a link to the Creative Commons license, and indicate if changes were made. 
$75 \%$ of the food insecure people lived in rural areas of developing countries, in which two thirds of these lived in just seven countries (Bangladesh, China, Democratic Republic of Congo, Ethiopia, India, Indonesia and Pakistan) (Keatinge et al. 2011; Khush et al. 2012; Sani and Kemaw 2017).

As a part of Africa and developing world, Ethiopia is one of the most food-insecure and famine affected countries as large portion of the country's population has been affected by chronic and transitory food insecurity (Abduselam 2017). Over 30\% of the population is below the food poverty line, unable to afford the minimum caloric intake for a healthy and active life (CSA (Central statistical agency) 2014). Furthermore, FAO (2012) finding figured out that $52 \%$ of the rural population was food insecure i.e. consume below the minimum recommended daily intake of $2100 \mathrm{kcal} / \mathrm{AE} /$ day, which led the rural households to temporarily depend on relief food assistance. As a result, more than 8.5 million people were in need of emergency food aid and assistance (WFP 2017). Moreover, under-nutrition has been a persistent problem as $44 \%$ of children in the country were stunted, $10 \%$ of children were considered to have low weight-for-height (wasting) and $29 \%$ of children were considered to have underweight (low weight-for-age). Besides, under-nutrition was predominant in rural areas in which stunting accounts for $46 \%$, wasting accounts for $10 \%$, and underweight accounts for $30 \%$ of rural children in the country (CSA (Central statistical agency) 2011).

The western part of Ethiopia, Assosa zonein particular, is hit by high degree of incidence of food insecurity as agricultural production and productivity is highly vulnerable to climate variables (Sani and Kemaw 2017). In addition, Assosa zone is characterized by erratic and unreliable rainfall, land degradation, low per capita, poor infrastructure development, vulnerable groups (landless and the poor without assets, very small and fragmented land holders, female- headed households, families with large size, drought and pest affected households) which cause low agricultural production and food deficit in the area (Asfir 2016; AZBARD (Assosa Zone Agriculture and Rural Development Office) 2015). To reverse the food insecurity situation, the government has been formulating and implementing long-term strategies (such as Agricultural Development Led Industrialization, Growth \& Transformation Plan I and Growth \& Transformation Plan II) - which takes ensuring food security as its core objective (FAO 2012). In addition, to reduce the incidence of food insecurity households use different kinds of coping mechanisms in order to improve their livelihood. As to Gemechu et al. (2015) finding there is improvement in food security status of households in the country that shows the role of improvement in livelihood assets as well as investment strategies and policies that promoted households food security and concluded that there is still room for improvement. But, the improvement programs to be effective, they should be supported by location specific empirical evidences (Van der Veen and Tagel 2011). To this end, there is limitation of information on the issue in the study area. Hence, this study analyzes extent of food insecurity and its determinants along with the coping mechanisms opted by households against food insecurity and shortage in the study area. Thus, it addresses what factors affect households' extent of food insecurity and what coping mechanisms have been used by households against food insecurity and shortage in the study area. Various studies conducted in Ethiopia mainly focused on food availability and access dimension (Girma 2012; Mesfin 2014; Nigatu 2011; Arega 2015; Okyere et al. 2013; Hussein and Janekarnkij 2013; Motbainor et al. 2016) 
and others adopted $24 \mathrm{~h}$ or seven day recall method to capture the utilization dimension (Gemechu et al. 2015; Zemedu and Mesfin 2014; Beyene \& Muche, 2010) to address households' food security and its determinants. However, considering only the food availability and access measures do not fully address the actual food energy utilization by the households and the quality of the food consumed. In addition, the drawback of relying on seven day recall method is that as a part of developing countries the majority of rural households have weak access to formal education due to that they cannot accurately respond on the types and quantities of food items consumed. The novelty of this study is that it considered households' food consumption/utilization for seven consecutive days collected using weighed records method as food energy intake is sensitive to different unforeseen factors such as religion, weather, holidays, etc., which can be captured by taking weighted data..

The rest of the paper is organized as follows: section 2 provides the methodology employed; section 3 presents and discusses the results; and section 4 concludes and infers policy implications..

\section{Methodology}

The study area

Assosa zone, the study area, is one of the three administrative zones in Benishangul-Gumuz region of western Ethiopia. Administratively, the study area is divided into seven districts, namely; Assosa, Homosha, Bambasi, Menge, Kurmuk, Sherkole and Odabildi-Guli districts. The zone has a total population of 283,707 people, out of which 144,616 and 139,091 are male and female, respectively. Furthermore, $86.28 \%$ of the population lives in rural area and $13.72 \%$ lives in urban area. The population density of the study area is 28 persons per kilometer square (BGRDGA (Benishangul Gumuz Region Development Gap Assessment) 2010). Mixed farming (crop production and livestock rearing) system is the main sources of livelihood for the majority of the population in the area. Crop production is dominated by rain fed agriculture while irrigation is practiced on small scale level. The major livestock reared in the area are cattle, donkey, goats, sheep and poultry (AZBARD (Assosa Zone Agriculture and Rural Development Office) 2015).

\section{Sampling technique and sample size}

The study employed three-stage random sampling method to select sample households. In the first stage, out of 7 districts in Assosa zone, three districts (namely Assosa, Bambasi and Sherkole) were randomly selected. In the second stage, a total of 12 peasant associations (PAs) were randomly selected using probability proportional to the number of PAs in each sampled districts. The reason for selecting PAs was that, in the study area almost all the households relied on agriculture and the emphasis of this study was on assessing the extent of food insecurity of households working on agriculture and their coping mechanisms. In the third stage, a total of 276 sample household heads were randomly selected based on probability proportional to size of the households in the selected PAs. The sample size for this study was determined by using Yamane formula (Yamane 1967). 


$$
n=\frac{\mathrm{N}}{1+\mathrm{N}(e)^{2}}=\frac{40530}{1+\left(40530 \times 0.06^{2}\right)}=276
$$

Where $\mathrm{n}=$ designates the sample size, $\mathrm{N}=$ designates total number of estimated household heads in the study area (40530) and $\mathrm{e}=$ designates maximum variability or margin of error $(6 \%)$.

\section{Data set and collection methods}

For this study, primary data collected from sample households using interview schedule through the enumerators and the researchers was used. Particularly, primary data on the types and quantities of every food item consumed by the household head and his/her family members was collected using Weighed records method for 7 consecutive days from each sampled households. The reason for collecting the data from a single household for seven consecutive days was that food security is a sensitive issue that is affected by different unforeseen factors (religious, holidays, etc.) which can be captured by taking weighed data (Muche and Esubalew 2015). In addition to this, primary data on household's socio-demographic and socio-economic factors as well as on households' food insecurity and shortage coping mechanisms was obtained through interview schedule. Besides, focus group discussions and key informants interview were also employed to supplement the research finding with qualitative information.

\section{Method of data analysis}

To analyze the collected data, the study employed descriptive statistics, food insecurity index and Tobit model. Descriptive statistics such as mean, percentage and frequency were used to describe households' food kilocalorie intake status and to explore the coping mechanisms to food insecurity in the study area. Furthermore, the study used Foster, Greer and Thorbecke (FGT) food insecurity index in the computation of the incidence, depth and severity of food insecurity. This model is widely applicable in poverty analysis. It is a class of additively decomposable measure of poverty and food insecurity. Foster and Shorrocks $(1991,1988)$ branded the decomposable components of FGT measures as consistent poverty indices and argued that they make analysis of the poverty dominance easier. Particularly in food security analysis, the model is essential in analyzing the sources of change in food insecurity due to changes in the components i.e. to know the change in food insecurity is due to the incidence, or increasing deprivation of the food insecure, or because of kilocalorie short-fall below the food security line have become more unequal, or some combination of the above. Thus, in this study the model enables to estimate the three food insecurity indicators, namely the number of households below the food security line (headcount), the extent of the short-fall of the kilocalorie of the food insecure from the food security line (food insecurity gap) and the exact pattern of distribution of the kilocalorie of the food insecure households (squared food insecurity gap). Accordingly, the Foster et al. (1984) measure used in estimation of food insecurity index components is given as:

$$
\operatorname{FGT}(\alpha)=(1 / \mathrm{n}) \sum_{\mathrm{i}=1}^{\mathrm{q}}[(\mathrm{c}-\mathrm{yi}) / \mathrm{c}]^{\alpha}
$$

Where: FGT $(\alpha)$ is the FGT food insecurity index; $n$ is the number of sample households; $y_{i}$ is the measure of per adult equivalent food kilocalorie intake of the $i^{\text {th }}$ 
household; $c$ represents the cut off between food security and food insecurity households (expressed here in terms of caloric requirements of $2100 \mathrm{kcal}^{*}$ ); $q$ is the number of food-insecure households; and $\alpha$ is the weight attached to the severity of food insecurity. Regarding estimation of the model, when the weight attached to $\alpha=0$ the measure is simply the headcount ratio (incidence); when $\alpha=1$ the measure is food insecurity gap (depth of food insecurity); and when $\alpha=2$ the measure is squared food insecurity gap (severity of food insecurity).

Moreover, Tobit model was estimated to analyze determinants of extent of households' food insecurity in the study area. Studies confirmed that, when a particular dependent variable assumes some constant value for some observations and a continuous value for the rest observations, the appropriate model will be a Tobit model developed by Tobin (1958) (Wooldridge 2002; Sisay and Edriss 2013; Agyeman et al. 2014; Bukenya 2017). Tobit is an extension of the probit model and it is one approach to deal with the problem of censored data (Johnston and Dinardo 1997). Thus, in this study the dependent variable was a censored variable in which it assumed a constant or threshold value of $2100 \mathrm{kcal} / \mathrm{AE} / \mathrm{day}^{*}$ for food secure households and the actual food energy intake in kilocalorie for food insecure households. Suppose, however, that $Y_{\mathrm{i}}$ is observed if the latent variable $Y_{i}^{*}<2100 \mathrm{kcal}$ and is not observed if $\mathrm{Y}_{\mathrm{i}}^{*} \geq 2100 \mathrm{kcal}$. Then the observed $Y_{i}$ will be defined as:

$$
Y i= \begin{cases}Y i^{*}=\beta X i+U i & \text { if } Y^{*}<2100 \mathrm{kcal} \\ 2100 \mathrm{kcal} & \text { if } Y i^{*} \geq 2100 \mathrm{kcal}\end{cases}
$$

Where: $Y_{i}^{*}$ is the latent (unobserved) variable, $Y_{i}$ is the observed variable, $X_{i}$ is vector of explanatory variables, $U_{i}$ is a vector of error terms and $\beta$ is a vector of parameters to be estimated.

"Note that $2100 \mathrm{kcal} / \mathrm{AE} / \mathrm{day}$ is the threshold value of food security stated by FDRE (1996).

\section{Operational definition of variables in the study \\ Extent of food insecurity}

It is a limited dependent variable, taking the threshold value $(2100 \mathrm{kcal})$ if the total food energy intake is greater than or equal to the threshold value and assumed the actual food energy intake for those households whose energy intake level is less than the threshold value. The quantity of food items consumed was converted to gram and the caloric content was estimated by using the nutrient composition table of commonly eaten foods in Ethiopia. Moreover, the estimated food energy was converted into adult equivalent and reached at figure of food calorie in kilo calorie/day/AE. Accordingly, household food calorie intake per day per adult equivalent (HFCi) was measured as:

$$
\mathrm{HFCi}=\frac{\text { Total calorie consumed by a household }}{\text { Household size in Adult equivalent } * 7}
$$

\section{Nature of settlement of the household heads}

This is a dummy variable used to indicate origin of household's. The variable took the value of 1 if respondents were settlers and 0 if natives. As depicted in Asfir (2016), unlike settlers, native households in the study area were highly resistant to accept new 
technologies. However, studies argued that adoption of new technologies improves agricultural production and productivity (Tsegaye and Bekele 2012) which in turn reduces households' exposure to incidence of food shortage and insecurity. In this study, this variable was hypothesized to affect extent of households' food insecurity negatively.

\section{Sex of head of household}

It is a dummy variable taking the value 1 if the sex of household is male and 0 , otherwise. As to Baten and Khan (2010) finding, female-headed households can find it difficult than men to gain access to valuable resource, which helps them to improve production and gain more income, this in turn increases their probability of being food insecure. Thus, in this study, it was expected to affect extent of households' food insecurity negatively.

\section{Age of head of household}

It is a continuous variable measured in years. Many studies argued that young households' heads are stronger and energetic than elderly households as they are expected to cultivate larger-size farm and obtain high yield (Abafita and Kim, 2014; Babatunde 2007). Hence, in this study age of the household head was expected to affect extent of food insecurity negatively.

\section{Educational level of head of household}

It is a continuous variable measured in years of schooling of the household head. Education, which is a social capital, has a positive impact on household ability to take good and well-informed production and nutritional status (Babatunde 2007). Besides, Amaza et al. (2006) argued that households with higher years of schooling are less likely to be food insecure as it enables them to produce more and consume more. Thus, higher years of schooling was expected to affect extent of food insecurity negatively.

\section{Family size}

It is a continuous variable which refers to the number of family members of the household. Studies argued that larger family size tends to exert more pressure on households consumption than the labor it contributes to production (Stephen and Samuel 2013; Muche et al. 2014). Therefore, in this study, larger household size was expected to affect extent food insecurity positively.

\section{Dependency ratio}

It refers to the proportion of economically inactive labor force (less than 15 and above 65 years old) to the active labor force (between 15 and 65 years old (Velasco 2003). Due to scarcity of resources, higher dependency ratio imposes burden on the active and inactive member of household to fulfill their immediate food demands (Muche et al. 2014). Besides, higher dependency ratio indicates that the labor force is small, with a constraint on the household per capita income and consumption, which also influences the wellbeing of the household members (Nugusse et al. 2013). In this study, it was expected to positively affect extent of households' food insecurity. 


\section{Livestock ownership (excluding oxen and donkey)}

It is a continuous variable measured by the number of Tropical Livestock Unit (TLU). Livestock are important source of food and income for rural households. Households with more livestock produce more milk, milk products and meat for direct consumption. Besides, livestock enable the farm households to have better chance to earn more income from selling livestock and livestock products which assist them to purchase stable food during food shortage and invest in purchasing of farm inputs that increase food production, and ensure household food security (Mitiku et al. 2012; Gemechu et al. 2015). Livestock possession mitigates vulnerability of households during crop failures and other calamities (Abafita and Kim, 2014). Thus, this study hypothesized that owning more TLU of livestock was expected to have negative effect on the extent of food insecurity of households.

\section{Number of oxen and donkey owned}

It is a continuous variable measured in numbers owned. Oxen and donkey serve as a source of traction power in many developing countries, thereby significantly affecting household's crop production. Animal traction power enables households to cultivate their land; others land through renting, share cropping, and execute agricultural operations timely that will enhance households access to food items (Muche et al. 2014). Accordingly, in this study more number of oxen and donkeys owned by a household was expected to affect the extent of food insecurity negatively.

\section{Cultivated land size}

It is a continuous variable which refers to the total land cultivated by a household in the past one year production period. A larger size of cultivated land implies more production and availability of food grains (Mitiku et al. 2012). Therefore, higher production and the increased availability of grains produced help to insure food security status of households (Asmelash 2015). Hence, the size of cultivated land was expected to have negative impact on extent of food insecurity.

\section{Access to irrigation}

It is a dummy variable taking the value 1 if the farmers have access to irrigation and 0 , otherwise. Irrigation, as one of the technology options available, enables smallholder farmers to directly produce consumable food grains and/or diversify their cropping and supplement moisture deficiency in agriculture so that it helps to increase production and food consumption (Van der Veen and Tagel 2011). Thus, in this study, it was expected to have negative impact on extent of households' food insecurity.

\section{Farm income}

This is a continuous variable which measures the amount of income obtained from crop production and livestock rearing measured in US Dollar. According to Beyene and Muche (2010) finding, higher farm income earning enables farmers to purchase different nutritious food items to satisfy their family food demand. Thus, for this study, farm income was hypothesized to affect extent of households' food insecurity negatively. 


\section{Off/non-farm income}

It is a continuous variable which measures the amount of cash income obtained by any household member from off-farm and non-farm activities measured in US Dollar. Studies argued that households with higher off-farm and non-farm income are less likely to be food insecure as it enables them to purchase different food items to satisfy their family needs (Beyene \& Muche, 2010; Abafita and Kim 2014). Thus, off/non-farm income was expected to affect extent of food insecurity negatively.

\section{Cost of inputs}

It is a continuous variable measured in US Dollar by converting the amount of the agricultural inputs used (such as fertilizers, seeds, pesticides, chemicals, and other agricultural implements.) into monetary value based on their market price. Investing higher amount of money on farm inputs helps farmers to increase their crop production and livestock breeding (Arene and Anyaeji, 2010). In this study, it was expected to affect extent of households' food insecurity negatively.

\section{Access to training}

It is a dummy variable that takes value 1 if a household gets access to agricultural related training and 0, otherwise. Formal agricultural training on modern technologies (proper types and rates of fertilizer application, improved varieties of seeds, agro-chemicals, etc.) helps farmers to get better production, and then this most likely leads to obtain more income to fulfill their family requirements by enhancing their agricultural production skills, knowledge and experiences (Yishak et al., 2014). Therefore, in this study, it was expected to affect extent of households' food insecurity negatively.

\section{Frequency of extension contact}

It is a continuous variable measured in number of visits by extension agent per year. More frequent extension contact enhances households' access to better crop production techniques, improved input as well as other production incentives, and thishelps to improve food energy intake status of households (Hussein and Janekarnkij 2013; Nugusse et al. 2013). Accordingly, in this study more number of extension contacts were expected to affect extent of households' food insecurity negatively.

\section{Access to credit}

It is a dummy variable, which takes the value 1 if the household had access to credit and 0 otherwise. Availability of credit eases the cash constraints and allows farmers to purchase inputs such as fertilizer, improved crop varieties, and irrigation facilities; which in turn enhance food production and ultimately increase household food energy intake (Stephen and Samuel 2013). In this study, it was expected to affect extent of households' food insecurity negatively.

\section{Remittance and aid}

It is a dummy variable, which takes the value 1 if the household had access to remittance and aid in the past one year and 0 otherwise. Both remittance and aid,from 
governmental and non-governmental organizations are important to smooth consumption in the case of shock and shortage for the time of emergency (Okyere et al. 2013; Mesfin 2014). Thus, for this study, it was expected to negatively affect extent of households' food insecurity.

\section{Distance to market}

it is a continuous variable measured in kilometer $(\mathrm{km})$. Proximity to the market may create opportunity of more income by providing off/non- farm employment opportunities, which determine income level of rural households. In addition, the closer the farmer is to the market the more likely the farmer gets valuable information, purchase agricultural inputs and final products required for family consumption. Therefore, this variable was expected to positively determine households' extent of food insecurity.

\section{Results and discussion}

\section{Socio-demographic characteristics of households}

For this study, a primary data collected from a total of 276 sampled household heads was used. From the total samples, $89.13 \%$ of household heads were male and the rest $10.87 \%$ were female, and this figure indicates that male headed households were owners of major livelihood assets as usual. In addition, $43.84 \%$ of the sampled household heads were settlers and the rest (56.16\%) were natives, and it shows that more than half of the samples were drawn from natives. Regarding the marital status of the households, the majority (85.5\%) of the households were married households followed by divorced (6.89\%), widowed (4.34\%) and single (3.27\%) households. Furthermore, the age distribution of the households range from 23 to 78 years and the majorities were in 30-40 year age group (47.83\%) and the least were in the age group of below 30 years $(5.79 \%)$. Moreover, the majority (58.33\%) of the respondents had a family member falling between 5 and 10 members group followed by $<5$ member group $(37.67 \%)$ and $>10$ member group (4\%). As to households' literacy status, the study indicated that $46.38 \%$ of the respondents had access to formal education (Table 1).

The finding of the study also figured out that the majority (74.28\%) of the households were relying on combining crop and livestock production as an economic activity followed by crop production alone (21.74\%) and livestock production (3.98\%). In addition, it showed that $56.16 \%$ of the sampled households had access to irrigation, indicating that in the study area more than half of the samples were beneficiaries of the irrigation water. Regarding the income earning from farming activities, $44.93 \%$ of the households were earning less than 117.65 USD followed by 117.65-235.29 USDincome group (16.3\%), 235.29-411.76 USD income group (15.94\%), 411.76-764.71 USD income group (12.68\%) and greater than 764.71 USD (10.15\%). Besides, the majority $(62.68 \%)$ of the households was not engaged in any type of off-farm and non-farm activities and the rest (37.32\%) were earning a positive income from off-farm and non-farm activities. From the total households, $36.96 \%$ cultivated a land size of $\leq 0.5$ ha followed by between $0.5-1$ ha $(33.70 \%),>1$ ha $(25.36 \%)$ and 0 ha $(3.98 \%)$. Furthermore, the study finding showed that $80.79 \%$ of the sampled households had no access to credit service in the study area, implying that the majority of the households did not recieve any type of credit from formal and informal sources. As to households access 
Table 1 Socio-demographic characteristics of the sampled households

\begin{tabular}{|c|c|c|}
\hline Variables & Frequency (N) & Percent (\%) \\
\hline \multicolumn{3}{|l|}{ Household head } \\
\hline Female & 30 & 10.87 \\
\hline Male & 246 & 89.13 \\
\hline \multicolumn{3}{|c|}{ Nature of households settlement } \\
\hline Native & 155 & 56.16 \\
\hline Settler & 121 & 43.84 \\
\hline \multicolumn{3}{|l|}{ Marital status: } \\
\hline Single & 9 & 3.27 \\
\hline Married & 236 & 85.5 \\
\hline Divorced & 19 & 6.89 \\
\hline Widowed & 12 & 4.34 \\
\hline \multicolumn{3}{|l|}{ Age of the household head } \\
\hline$\leq 30$ & 16 & 5.79 \\
\hline $30-40$ & 132 & 47.83 \\
\hline $40-50$ & 102 & 36.96 \\
\hline$\geq 50$ & 26 & 9.42 \\
\hline \multicolumn{3}{|l|}{ Family size } \\
\hline$<5$ & 104 & 37.67 \\
\hline $5-10$ & 161 & 58.33 \\
\hline$>10$ & 11 & 4 \\
\hline \multicolumn{3}{|l|}{ Literacy status } \\
\hline No formal education & 148 & 53.62 \\
\hline Have a formal education & 128 & 46.38 \\
\hline \multicolumn{3}{|l|}{ Agricultural activities } \\
\hline Crop production & 60 & 21.74 \\
\hline Livestock production & 11 & 3.98 \\
\hline Both & 205 & 74.28 \\
\hline \multicolumn{3}{|l|}{ Access to irrigation } \\
\hline Non-users & 121 & 43.84 \\
\hline Users & 155 & 56.16 \\
\hline \multicolumn{3}{|l|}{ Farm income (USDa) } \\
\hline$<117.65$ & 124 & 44.93 \\
\hline $117.65-235.29$ & 44 & 15.94 \\
\hline 235.29-411.76 & 45 & 16.30 \\
\hline $411.76-764.71$ & 35 & 12.68 \\
\hline$>764.71$ & 28 & 10.15 \\
\hline \multicolumn{3}{|l|}{ Off/non-farm income (USD $\left.{ }^{a}\right)$} \\
\hline Non-participant & 173 & 62.68 \\
\hline$<117.65$ & 29 & 10.51 \\
\hline $117.65-352.94$ & 48 & 17.39 \\
\hline$>352.94$ & 26 & 9.42 \\
\hline \multicolumn{3}{|l|}{ Cultivated land (ha) } \\
\hline 0 & 11 & 3.98 \\
\hline$\leq 0.5$ & 102 & 36.96 \\
\hline
\end{tabular}


Table 1 Socio-demographic characteristics of the sampled households (Continued)

\begin{tabular}{lll}
\hline Variables & Frequency $(\mathrm{N})$ & Percent (\%) \\
\hline $0.5-1$ & 93 & 33.70 \\
$>1$ & 70 & 25.36 \\
Access to credit & 223 & 80.79 \\
$\quad$ No & 53 & 19.21 \\
Yes & & \\
Remittance and aid & 262 & 94.93 \\
No & 14 & 5.07 \\
Yes & & \\
Distance to market $(\mathrm{km})$ & 132 & 47.83 \\
$<5$ & 73 & 26.45 \\
$5-10$ & 71 & 25.72 \\
$>10$ & 73 \\
\hline
\end{tabular}

Source: Estimated result (2017), $N=276 ;{ }^{\text {a }}$ denotes 1 USD $=$ Ethiopian Birr 17

to remittance and aid, only $5.07 \%$ of the households had obtained remittance and aid from different sources. Moreover, 47.83\% of households market distance from their residence was less than $5 \mathrm{~km}$ followed by distance falling between 5 and $10 \mathrm{~km}$ $(26.45 \%)$ and greater than $10 \mathrm{~km}(25.72 \%)$ (Table 1$)$.

\section{Households food security and energy intake in the study area}

In this study, data on the type and quantity of food items consumed by the household for seven consecutive days were collected using weighed records method, and it was converted to kilocalorie and then divided to household size measured in $\mathrm{AE}$ and number of days. Following this, the amount of energy utilized in kilocalorie by the household was compared with the minimum subsistence requirement per adult per day (i.e. $2100 \mathrm{kcal}$ ). Accordingly, households in the study area were mainly consuming food items of maize products (such as white porridge, white bread, 'injera, and whole roasted, white' kitaa'), wheat products (such as bread and 'kitaa'), and teff products (such as 'injera' and porriage). Besides, vegetables such as onion, cabbage, tomato, and green pepper as well as livestock and poultry products such as milk, meat, egg, cheese and butter were also consumed by the households. Moreover, the locally known food item called 'kenkes' and oil seed products were among the food items consumed by the households. After conversion of the food items consumed to $\mathrm{kcal} / \mathrm{AE} / \mathrm{day}$, the result of the study revealed that 148 (53.62\%) of the sampled households were found to be food insecure and 128 (46.38\%) of the sampled households were food secure (Table 2). This implied that more than half of the households in the study area were food insecure. Regarding the food insecurity status within each district, it is found that $58.04 \%$ of households in Assosa district were food insecure. This indicates, in the district, the incidence of food insecurity was higher i.e. there were more number of food insecure households as compared to the food secure ones and it was mainly attributed to the incidence of pest outbreak in the 2016/17 production season which led to loss of thousands of quintals of crop production in the district. Furthermore, the study revealed that $48.89 \%$ and $48.84 \%$ of the households were food insecure in Bambasi and 
Table 2 Households food security status and its breakdown between districts

\begin{tabular}{|c|c|c|c|c|c|c|c|}
\hline \multirow[t]{2}{*}{ District } & \multicolumn{2}{|c|}{ Food insecure } & \multicolumn{2}{|c|}{ Food secure } & \multicolumn{2}{|c|}{ Total } & \multirow{2}{*}{$\begin{array}{l}\% \text { of } \\
\text { food } \\
\text { insecure } \\
\text { within } \\
\text { the } \\
\text { districts }\end{array}$} \\
\hline & $\mathrm{N}$ & $\%$ & $\mathrm{~N}$ & $\%$ & $\mathrm{~N}^{a}$ & $\%$ & \\
\hline Assosa & 83 & 30.07 & 60 & 21.74 & 143 & 51.81 & 58.04 \\
\hline Bambasi & 44 & 15.94 & 46 & 16.67 & 90 & 32.61 & 48.89 \\
\hline Sherkole & 21 & 7.61 & 22 & 7.97 & 43 & 15.58 & 48.84 \\
\hline Total & 148 & 53.62 & 128 & 46.38 & 276 & 100 & \\
\hline
\end{tabular}

Source: Authors computation (2017), N = 276; ${ }^{a}$ indicates the samples drawn from each district based on probability proportional to size

Sherkole districts, respectively (Table 2). Though more than half of the households were food secure, the state of food insecurity was high in both districts. Generally, the incidence of food insecurity was relatively higher in Assosa district as compared to the other two districts.

Moreover, the study finding indicated that the mean calorie intake of the sampled households was $1991.42 \mathrm{kcal}$ per adult equivalent per day, which was lower than the minimum calorie requirement of $2100 \mathrm{kcal}$ for a healthy and productive life, with maximum and minimum level of kilocalorie energy intake being 4286.91 and 597.65, respectively. Besides, the calorie intake of food insecure households ranges from $597.65 \mathrm{kcal}$ and $2048.13 \mathrm{kcal}$ with mean kilocalorie energy intake of 1440.37 . The finding also revealed that the mean energy intake of food secure households was $2628.56 \mathrm{kcal}$ per adult equivalent per day with the maximum and minimum energy intakes being 4286.91 and $2116.67 \mathrm{kcal}$ per adult equivalent per day, respectively (Table 3).

\section{Households extent of food insecurity in the study area}

FGT food insecurity index was used to assess the extent of food insecurity in the study area. Thus, the finding of head count ratio from food insecurity index indicated that the incidence of food insecurity was $53.62 \%$, and it indicated that $53.62 \%$ of the households were actually in the state of food insecurity, that is, unable to get the minimum recommended calorie for subsistence. The food insecurity gap, which is a measure of depth of food insecurity, pointed out that each food insecure household needed $16.84 \%$ of the daily caloric requirement to bring them up to the recommended daily caloric requirement level. This means, on average, the households need to be supplied with $16.84 \%$ of the daily minimum calorie requirement to get out of the food insecurity problem. The average extent of the calorie deficiency gap for the sampled households was, therefore, $353.64 \mathrm{Kcal} / \mathrm{AE} /$ day; which means, on average $353.64 \mathrm{Kcal} / \mathrm{AE} /$ day of

Table 3 Summary of households' energy intake in the study area

\begin{tabular}{|c|c|c|c|c|c|c|c|c|c|}
\hline \multirow[t]{2}{*}{$\begin{array}{l}\text { Variable } \\
\text { nat }\end{array}$} & \multicolumn{3}{|c|}{ Food insecure $(N=148)$} & \multicolumn{3}{|c|}{ Food secure $(N=128)$} & \multicolumn{3}{|c|}{ Total $(N=276)$} \\
\hline & Min. & Max. & Mean & Min. & Max. & Mean & Min. & Max. & Mean \\
\hline $\begin{array}{l}\text { Total energy intake (kcal/AE/ } \\
\text { day) }\end{array}$ & 597.65 & 2048.13 & 1440.37 & 2116.67 & 4286.91 & 2628.56 & 597.65 & 4286.91 & 1991.42 \\
\hline
\end{tabular}

Source: Authors computation (2017), N = 276; estimated based on a data obtained from households for seven consecutive days 
additional food energy would be needed to lift the households out of food insecurity, then at least in theory, food insecurity could be eliminated. Moreover, the result of squared food insecurity gap from food insecurity index figured out that the severity of food insecurity in the study area was $7.32 \%$ (Table 4 ).

\section{Determinants of the extent of households food insecurity in the study area}

Tobit model was estimated to analyze the determinants of the extent of households' food insecurity. Accordingly, results from the Tobit model using data obtained from 276 sample households (of which 128 were censored/food secure according to the model result) are presented in Table 5 . The overall model is significant at $1 \%$ as indicated by the likelihood ratio test (Prob $>X^{2}=0.0001$ ). In addition, the model estimate revealed that out of the 18 explanatory variables, 7 variables were found to have a significant impact on households' extent of food insecurity. Thus, only statistically significant variables at less than $10 \%$ probability levels were discussed.

\section{Age of the household head}

As expected, it affected household's level of energy intake negatively (extent of food insecurity positively) and significantly at $5 \%$ significance level in the study area. The marginal effect, from of the model result, indicated that a one year increase in the age, within food insecure households, increased the likelihood of household's extent of food insecurity by $448 \%$. This implies that old aged household heads within food insecure households were more likely to face higher degree of energy intake deficiency than younger ones. This is because as age increases households become less productive and have less courage to cultivate larger-size farm than young ones. In addition, mostly elder households have large number of families and their resources are distributed among the members, and this imposes pressure on their income to purchase consumable products. This finding is in line with the finding of Bukenya (2017).

\section{Family size}

As expected, this variable negatively and significantly affected households' intensity of energy intake at $10 \%$ significance level. From the model output, the marginal effect revealed that one extra person in the household increased the probability of household's intensity of food energy intake deficiency by $1211 \%$. This indicates that households with larger family size tend to be more food energy deficient than households with smaller family size in the study area. This is due to the reason that, households with large family size could be composed of large number of non-productive members; which imposes high burden on the labor force and food available to each person and ultimately end up with

Table 4 FGT food insecurity index result on extent of food insecurity in the study area

\begin{tabular}{ll}
\hline FGT measures & Percent (\%) \\
\hline Head count ratio (Incidence of food insecurity) & 53.62 \\
Food insecurity gap (Depth of food insecurity & 16.84 \\
Squared food insecurity gap (Severity of food insecurity) & b \\
\hline
\end{tabular}

Source: Computed result (2017); where ${ }^{a}$ indicates estimation from the total sample and ${ }^{b}$ indicates estimation from food insecure (148) households 
Table 5 Tobit model result on determinants of extent of food insecurity in the study area

\begin{tabular}{|c|c|c|c|c|c|c|}
\hline Explanatory variables & Coefficients & Std. dev. & $P>|t|$ & $\mathrm{ME}(\mathrm{dy} / \mathrm{dx})$ & Std. dev. & $P>|t|$ \\
\hline Settlement of the $\mathrm{HH}$ head & -92.44 & 109.44 & 0.399 & -36.72 & 43.7 & 0.40 \\
\hline Sex of the HH head & 79.19 & 146.82 & 0.590 & 32.18 & 61.31 & 0.60 \\
\hline Age of the $\mathrm{HH}$ head & $-11.34^{b}$ & 4.53 & 0.013 & $-4.48^{b}$ & 1.78 & 0.013 \\
\hline Education status of the $\mathrm{HH}$ head & -17.67 & 14.01 & 0.208 & -6.98 & 5.54 & 0.208 \\
\hline Family size & $-30.64^{c}$ & 18.24 & 0.094 & $-12.11^{c}$ & 7.19 & 0.093 \\
\hline Dependency ratio & 75.49 & 47.6 & 0.114 & 29.82 & 18.80 & 0.113 \\
\hline Livestock holding excluding Oxen and Donkey & 22.68 & 32.83 & 0.49 & 8.96 & 12.97 & 0.489 \\
\hline Number of Oxen and Donkey owned & 31.04 & 58.82 & 0.598 & 12.26 & 23.24 & 0.598 \\
\hline Cultivated land size & 56.50 & 76.67 & 0.462 & 22.32 & 30.28 & 0.461 \\
\hline Access to irrigation & $179.68^{c}$ & 95.25 & 0.06 & $70.98^{c}$ & 37.49 & 0.058 \\
\hline Farm income & $0.0194^{b}$ & 0.0097 & 0.049 & $0.0076^{\mathrm{b}}$ & 0.0038 & 0.047 \\
\hline Off-farm and non-farm income & $-0.0259^{b}$ & 0.0125 & 0.039 & $-0.0102^{b}$ & 0.0049 & 0.037 \\
\hline Input cost & -0.0469 & 0.044 & 0.292 & -0.018 & 0.0175 & 0.289 \\
\hline Access to training & -100.17 & 95.85 & 0.297 & -39.48 & 37.65 & 0.294 \\
\hline Frequency of extension contact & -2.77 & 6.78 & 0.684 & -1.093 & 2.68 & 0.683 \\
\hline Access to credit & $392.22^{\mathrm{a}}$ & 128.43 & 0.002 & $139.21^{\mathrm{a}}$ & 40.64 & 0.001 \\
\hline Access to remittance and aid & -262.06 & 207.49 & 0.208 & -115.09 & $' 100.66$ & 0.253 \\
\hline Distance to market & $20.70^{b}$ & 9.25 & 0.026 & $8.18^{b}$ & 3.64 & 0.025 \\
\hline Constant & $2287.975^{\mathrm{a}}$ & 273.45 & 0.000 & & & \\
\hline Sigma & 660.34 & 42.39 & & & & \\
\hline Number of observations & & 276 & & & & \\
\hline LR chi ${ }^{2}$ (18) & & 50.46 & & & & \\
\hline Log likelihood & & -1256.72 & & & & \\
\hline Prob> chi ${ }^{2}$ & & 0.0001 & & & & \\
\hline Pseudo $\mathrm{R}^{2}$ & & 0.0197 & & & & \\
\hline \multirow[t]{2}{*}{ Observation summary } & \multicolumn{6}{|c|}{148 uncensored observations } \\
\hline & \multicolumn{6}{|c|}{$\begin{array}{l}128 \text { right-censored observations at energy intake }>= \\
2100 \text { kcalorie }\end{array}$} \\
\hline
\end{tabular}

Estimated model result (2017), $\mathrm{N}=276$; where ${ }^{\mathrm{a} D e n o t e s}$ statistically significant at $1 \%,{ }^{\mathrm{b}}$ Denotes statistically significant at $5 \%$ and ${ }^{C}$ Denotes statistically significant at $10 \%$

difficulty to achieve food security. This finding supports the finding of Stephen and Samuel (2013).

\section{Access to irrigation}

It affected households' extent of food energy intake positively (extent of food insecurity negatively) and significantly at $10 \%$ significance level. From the model result, the marginal effect showed that having access to irrigation increased food insecure households' likelihood of the extent of food energy intake by $7098 \%$. This implies that households who had irrigation access were less likely to be food energy deficient than those who had no irrigation access, and the result supports the finding of Van der Veen and Tagel (2011). This is due to the fact that, access to irrigation helps households' to produce more than once in a year through mitigating water stress and reducing risks of crop 
failures and obtains more yields; thereby reducing the extent of food insecurity among the households.

\section{Total farm income}

As expected, it determined households' extent of food energy intake positively (extent of food insecurity negatively) and significantly at $5 \%$ significance level. From the model output, the marginal effect pointed out that a one birr (0.0588 USD) increase in farm income, within food insecure households, decreased the probability of their energy intake deficiency by $0.76 \%$. This indicates that higher farm income earning households were less likely to energy deficient than low farm income earning households in the study area. This is because higher farm income helps the farmers to purchase diversified and nutritious food items which in turn helps them to improve their food energy intake status (Bukenya 2017; Mitiku et al. 2012).

\section{Off-farm and non-farm income}

In contrary to the expectation, it negatively and significantly affected households' extent of energy intake at 5\% significance level. From the model result, the marginal effect confirmed that a one birr (0.0588 USD) increase in the off-farm and non-farm income increased the probability of food insecure households' food energy intake deficiency by $1.02 \%$. This indicates that food insecure households with higher off-farm and non-farm income earning were more likely to be food energy deficient than low earning households in the study area. This is because, in the study area, households engaged in off-farm and non-farm income earning activities focus on accumulating physical and financial resources to improve their future wellbeing than spending their income on purchasing food products to satisfy their current food requirement, and this result supports the finding of Indris (2012).

\section{Access to credit}

As expected, it affected households' extent of energy intake positively and significantly at $1 \%$ significance level. The marginal effect, from the model result, showed that having access to credit decreased food insecure household's probability of food energy deficiency by $13,921 \%$. This implies households who had access to credit service had less chance to be food energy deficient as compared to those who had no access to credit. This is due to the reason that, in the study area, households were receiving credit mainly in kind such as in the form of fertilizer, seed, herbicide, etc., from agricultural offices, and it enabled them to use their income in purchasing diverse and nutritious food items rather than various types of inputs to reduce the risk of high degree of food insecurity. Stephen and Samuel (2013) also reported similar finding.

\section{Distance to market}

As expected, this variable affected extent of household's food insecurity negatively and significantly at $5 \%$ probability level in the study area. From the model output, the marginal effect indicated that a one kilometer increase in the residence of households from the nearest market decreased the probability of food energy deficiency by $818 \%$. This implies that food insecure households living near the market center were more 
likely to be energy deficient than those living far from the market center. This is because, in the study area, households living far from the market center were mainly producing consumable product items as compared to those households living close to market center who were producing cash crops.

\section{Households coping mechanisms to food insecurity and shortage in the study area}

Studies conducted in Ethiopia argued that households adopt a range of coping mechanisms during food insecurity and/or food shortage (Sewnet 2015; Arega 2015). The results of the study confirmed that households in the study area adopted diversified coping mechanisms at times of food shortage and/or food insecurity. Accordingly, 81.9\% of the sampled households pursued reducing frequency of meal as a coping mechanism, followed by reducing the size of meal served (78.6\%) and working as a daily laborer (68.1\%). This implies that the majority of the households were adopting decreasing the number of meal serving time, size of meal and working as daily laborer as their coping mechanism to cope up with the risks of food shortage and/or food insecurity. Furthermore, the study also pointed out that 49.3, 48.6, 43.5, 37.7, 37.7, 35.9, 32.2, 29.7 and $5.07 \%$ of the sampled households were using sale fire wood and charcoal, engaging in wild fruit gathering, engaging in petty trade, selling livestock's, borrowing/loan, selling different assets, mining, migrating to cities and remittance and food aid, respectively, as coping mechanisms against food shortage and food insecurity in the study area (Table 6).

Moreover, the study result revealed that reducing meal size was the most effective and most important coping mechanism used by the large segment of the households (36.6\%), followed by reducing frequency of meal (27.9\%) and working as a daily laborer $(13.77 \%)$. In addition, the finding of the study showed that 11.23, 2.9, 2.9, 2.17, 1.09, $0.72,0.36$ and $0.36 \%$ of the sampled households adopted selling livestock's, remittance and food aid, migration, wild fruit gathering, selling wood and charcoal, receiving loan, selling different assets and engaging petty trade, respectively, as their most effective and important coping mechanisms against food shortage and food insecurity (Table 7). This

Table 6 Households coping mechanisms against food insecurity and/or shortage

\begin{tabular}{lll}
\hline Households coping mechanisms & Frequency(N) & Percent (\%) \\
\hline Reducing frequency of meal & 226 & 81.9 \\
Reducing meal size & 217 & 78.6 \\
Selling livestock's & 104 & 37.7 \\
Engaging in wild fruit gathering & 134 & 48.6 \\
Selling different assets & 99 & 35.9 \\
Migrating to cities & 82 & 29.7 \\
Receiving loan & 104 & 37.7 \\
Remittance and Food aid & 14 & 5.07 \\
Selling wood, charcoal, etc & 136 & 49.3 \\
Gold mining & 89 & 32.2 \\
Engagement in petty trade & 120 & 43.5 \\
working as a daily laborer & 188 & 68.1 \\
\hline
\end{tabular}

Source: Estimated result (2017), $\mathrm{N}=276$; Note that a single household can present all the coping mechanism used at the time of food insecurity and/or shortage 
Table 7 Households most effective coping mechanisms against food insecurity and food shortage in the study area

\begin{tabular}{lll}
\hline Households key coping mechanism & Frequency (N) & Percent (\%) \\
\hline Reducing frequency of meal & 77 & 27.90 \\
Reducing meal size & 101 & 36.60 \\
Selling livestock's & 31 & 11.23 \\
Engaging in wild fruit gathering & 6 & 2.17 \\
Selling different assets & 1 & 0.36 \\
Migrating to cities & 8 & 2.90 \\
Receiving loan & 2 & 0.72 \\
Remittance and Food aid & 8 & 2.90 \\
Selling wood, charcoal, etc & 3 & 1.09 \\
Working as a daily laborer & 38 & 13.77 \\
Engagement in petty trade & 1 & 0.36 \\
Total & 276 & 100 \\
\hline
\end{tabular}

Source: Estimated result (2017), N=276; Note that households were allowed to present the most effective coping mechanism used to cope up with the incidence of food insecurity and/or shortage

finding supports the findings of Sewnet (2015), Birara et al. (2015) and Woldeamanuel (2009) which concluded that rural households pursued various coping mechanisms when food crisis hits them so as to reduce the risk associated with food insecurity.

\section{Conclusions and recommendations}

Food insecurity and poverty are critical and persistent problems facing most Ethiopians today. In an effort to reverse the incidence of these problems, different studies recommended that improving the livelihood of the rural poor plays a key role. The improvement programs in the welfare of rural community to be effective, they need to be supported by empirical evidences that provide important input on households' food security for concerned bodies. Thus, this study assessed households' extent of food insecurity and its determinants along with the coping mechanisms opted against food insecurity and shortage in Assosa zone using a data collected from 276 sample households.

Accordingly, the findings of the study pointed out that the incidence of food insecurity (53.62\%) was high in the study area, with the depth and severity of food insecurity being $16.84 \%$ and $7.32 \%$, respectively. This implies that more than half of the households in the study area were food insecure. In addition, the estimated Tobit model results revealed that farm income, access to irrigation, access to credit and distance to market negatively affected the extent of households' food insecurity; whereas age of the household head, family size and off-farm and non-farm income positively affected households extent of food insecurity. To cope up with the food insecurity and shortage situation, households opted reducing frequency of meal, reducing the size of meal served, working as a daily laborer, selling fire wood and charcoal, engaging in wild fruit gathering and petty trade as top six coping mechanisms in the study area.

Thus, urgent actions directed towards reducing and/or eliminating rural households' food insecurity in the study area should focus on: 
- Awareness creation on effective family planning and the impact of large family size on ensuring food security, and awareness creation and capacity building for elder households through ensuring the availability and dissemination of accurate information should be strengthened.

- Enhancing rural household's access to credit as it enables them to purchase different inputs to improve their production and consumable products and thereby helps them to reduce and/or eliminate food insecurity and improve their wellbeing.

- Construction of irrigation schemes as access to irrigation enables households to produce more than once in a year through reducing water stress and the risk of crop failure and thereby helps them to reduce and/or eliminate food insecurity.

- Enhancing household's farm income-earning opportunities through provision of sufficient input to enhance agricultural production and productivity; and improving households' technical skill as well as their awareness on utilization of the off-farm and non-farm income to improve households' food security situation.

- Even though, better access to markets assumed to reduce transport and other market related transaction costs, the study finding indicated the opposite. Therefore, enhancing households' awareness about the importance of better access to markets on their informed decision regarding their choice of output to be produced and products to be purchased in the market that helps the households to enhance their food security status in the near future.

- Generally, as a policy implication the government should exhaustively work on promoting irrigation, facilitating credit availability and subsidize the farmers to reverse the problem of food insecurity and to enhance households coping capacity to food shortage and/or insecurity. Besides, this study has attempted to come up with the result of the analysis with defined scope however a lot remained to be unanswered. To provide basic information on the determinants of food security and extent of food insecurity, the social, political, natural and environmental dimensions, descriptive data on purchasing patterns of food insecure, specific characteristics that make rural poor more vulnerable to food insecurity demands future researchers' attention.

\section{Abbreviations}

AE: Adult equivalent; AZBARD: Assosa Zone Bureau of Agriculture and Rural Development; BGRDGA: Benishangul Gumuz Region Development Gap Assessment; CSA: Central Statistical Agency; FAO: Food and Agriculture Organization; FDRE: Federal Democratic Republic of Ethiopia; FGT: Foster, Greer and Thorbecke; HFCi: Household food calorie intake; kcal: Kilocalorie; PA: Peasant Association; USD: United States Dollar; USGAO: United State Government Accountability Office; WFP: World Food Program

\section{Acknowledgements}

The authors are grateful to Assosa University for providing both financial and technical assistance in the research work. We also sincerely thank the local communities in our research area, Assosa Zone, and all the enumerators for their valuable efforts. Furthermore, we also thank Assosa university Agricultural Economics staff members for their valuable assistance during the study.

Funding

Assosa University supported this research work both financially and logistically. 


\section{Competing interests}

The authors declare that they have no competing interests.

\section{Publisher's Note}

Springer Nature remains neutral with regard to jurisdictional claims in published maps and institutional affiliations.

\section{Author details}

${ }^{1}$ Department of Agricultural Economics, College of Agriculture and Natural Resource, Wolkite University, Wolkite, Ethiopia. ${ }^{2}$ Department of Agricultural Economics, College of Agriculture and Natural Resource, Debre Brehan University, Debre Brehan, Ethiopia.

Received: 29 January 2018 Accepted: 26 February 2019

Published online: 19 March 2019

\section{References}

Abafita J, Kim K (2014) Determinants of household food security in rural Ethiopia: an empirical analysis. J Rural Dev $37(2): 129-157$

Abduselam A (2017) Food security situation in Ethiopia: a review study. Int J Health Econ Policy 2(3):86-96. https://doi.org/10. 11648/j.hep.20170203.11

Agyeman B, Asuming-Brempong S, Onumah E (2014) Determinants of Income Diversification of Farm Households in the Western Region of Ghana. Q J Int Agric 53(1):55-72

Amaza P, Umeh J, Helsen J, Adejobi A (2006) Determinants and measurement of food insecurity in Nigeria: some empirical policy guide. Presented at international association of agricultural economists annual meeting, Queensland August 12-18

Arega B (2015) Coping strategies and household food security in drought-prone areas in Ethiopia: the case of lay Gayint District. GJDS 12(1 \& 2):1-18

Arene C, Anyaeji J, (2010) Determinants of Food Security among Households in Nigeria. Pak J Soc Sci 30: 9-16.

Asfir S (2016) Determinants of rural households livelihood strategies: evidence from Western Ethiopia. J Econ Sustain Dev 7(15):103-109

Asmelash M (2015) Rural households food security status and its determinants: the case of Laelaymychew woreda, central zone of Tigray, Ethiopia. J Agric Ext Rural Dev 6(5):162-167

AZBARD (Assosa Zone Agriculture and Rural Development Office) (2015) Annual report of Assosa zone of Benishangul Gumuz regional state, Ethiopia 2015

Babatunde R (2007) Factors influencing food security status of rural farming household in north Central Nigeria. Agric J 2(3):351-357

Baten MA, Khan NA (2010) Gender issue in climate change discourse: theory versus reality. Unnayan Onneshan, Dhaka Beyene F, Muche M (2010) Determinants of food security among rural households of Central Ethiopia: an empirical analysis. Quarterly Journal of International Agriculture 49(4): 299-318.

BGRDGA (Benishangul Gumuz Region Development Gap Assessment) (2010) Development Gap Assessment and Recommendations for Equitable and Accelerated Development Draft report

Birara E, Muche M, Tadesse S (2015) Assessment of food security situation in Ethiopia. World J Dairy and Food Sci 10(1):37-43

Bukenya O (2017) Determinants of food insecurity in Huntsville, Alabama, Metropolitan Area. J Food Distribution Res 48(1):73-80

CSA (Central statistical agency) (2011) Ethiopia mini demographic and health survey report, Addis Ababa, Ethiopia

CSA (Central statistical agency) (2014) Ethiopia mini demographic and health survey report, Addis Ababa, Ethiopia

FAO (2012) FAO crop and food security assessment mission to Ethiopia. Special report. P 25-30. Available online at http:// www.wfp.org/content/ethiopia-faowfp-crop-and-food-security-assessment-mission-april-2012

FAO (2014) The state of food insecurity in the world 2014. Strengthening the enabling environment for food security and nutrition. Food and Agriculture Organization, Rome. Available online at http://www.fao.org/3/a-i4030e.pdf

FAO (2015) The state of food insecurity in the world. Food and Agriculture Organization of the United Nations, Rome

FDRE (1996): Federal Democratic Republic of Ethiopia. Food Security Strategy Food Security Assessment, Regional Overview Information Bulletin

Foster J, Greer J, Thorbecke E (1984) A class of decomposable poverty measures. Econometrica 52(3):761-766

Foster J, Shorrocks A (1988) Inequality and poverty orderings. Eur Econ Rev 32:654-662

Foster J, Shorrocks A (1991) Subgroup consistent poverty indices. Econometrica 59:687-709

Gemechu F, Zemedu L, Yousuf J (2015) Determinants of farm household food security in Hawi Gudina district, West Hararghe zone, Oromia regional state, Ethiopia. Wudpecker J Agric Res 4(6):066-074

Girma G (2012) Determinants of food insecurity among households in Addis Ababa City, Ethiopia. Interdisciplin Descrip Complex Syst 10(2):159-173

Hussein W, Janekarnkij P (2013) Determinants of rural household food security in Jigjiga District of Ethiopia. Kasetsart J Soc Sci 34:171-180

Idrisa YL, Gwary MM, Shehu H (2008) Analysis of food security status among farming households in jere local government of Borno state, Nigeria. J Tropic Agric Food Environ Ext 7(3):199-205

IFAD (2011) Rural groups and the commercialization of smallholder farming: targeting and development strategies (draft). In: Issues and perspectives from a review of IOE evaluation reports and recent IFAD country strategies and project designs. International Fund for Agricultural Development, Rome

Indris S (2012) Assessment of food insecurity, its determinants and coping mechanisms among pastoral households: the case of Zone One Chifra District Afar National Regional State. Unpublished M.Sc. Thesis, School of Graduate Studies, Haramaya University, Ethiopia.

Johnston J, Dinardo J (1997) Econometric methods, 4th edn. McGraw-Hill, New York 
Keatinge JD, Yang R-Y, Hughes J d'A, Easdown WJ, Holmer R (2011) The importance of vegetables in ensuring both food and nutritional security in attainment of the millennium development goals. Food Secur 3:491-501

Khush G, Lee S, Cho Jl, Jeon JS (2012) Bio fortification of crops for reducing malnutrition. Plant Biotechnol Rep 6:195-202

Mesfin W (2014) Determinants of households vulnerability to food insecurity in Ethiopia: econometric analysis of rural and urban households. J Econ Sustainable Dev 5(24):70-79

Mitiku A, Fufa B, Tadese B (2012) Empirical analysis of the determinants of rural households food security in southern Ethiopia: the case of Shashemene District. Basic Res J Agric Sci Rev 1(6):132-138

Motbainor A, Worku A, Kumie A (2016) Level and determinants of food insecurity in east and west Gojjam zones of Amhara region, Ethiopia: a community based comparative cross-sectional study. BMC Public Health 16:503

Muche M, Birara E, Tesfalem K (2014) Determinants of food security among Southwest Ethiopia rural households. Food Sci Technol 2(7):93-100

Muche M, Esubalew T (2015) Analysis of household level determinants of food security in Jimma zone, Ethiopia. J Econ Sustain Dev 6(9):230-240

Nigatu R (2011) Small holder farmers coping strategies to household food insecurity and hunger in southern Ethiopia. Ethiopian J Environ Stud Manage 4(1):39-48

Nugusse W, Huylenbroeck G, Buysse J (2013) Household food security through cooperatives in northern Ethiopia. Int J Cooperative Stud 2(1):34-44

Okyere K, Ayalew D, Zerfu E (2013) Determinants of food security in selected agro-pastoral communities of Somali and Oromia regions, Ethiopia. J Food Sci Eng 3:453-471

Sani S, Kemaw B (2017) Assessment of households food security situation in Ethiopia: an empirical synthesis. Dev Country Stud 7(12):30-37

Sewnet Y (2015) Causes and coping mechanisms of food insecurity in rural Ethiopia. Agric Biol J North America 6(5):123-133. https://doi.org/10.5251/abjna.2015.6.5.123.13

Sisay E, Edriss A (2013) Determinants of food insecurity in Addis Ababa City, Ethiopia. paper presented at the 4th International Conference of the African Association of Agricultural Economists, Hammamet September 22-25, 2013

Stephen F, Samuel A (2013) Comparative study of determinants of food security in rural and urban households of Ashant region, Ghana. Int J Econ Manage Sci 2(10):29-42

Tobin J (1958) Estimation of relationship for limited dependent variables. Econometrica 26:29-39

Tsegaye M, Bekele H (2012) Impacts of adoption of improved wheat technologies on households' food consumption in southeastern Ethiopia: Selected Poster prepared for presentation at the International Association of Agricultural Economists (IAAE). Triennial Conference, Foz do Iguaçu, pp 18-24

Van der Veen A, Tagel G (2011) Effect of policy interventions on food security in Tigray, northern Ethiopia. Ecol Soc 16(1):18 https://doi.org/10.5751/ES-03895-160118

Velasco J (2003) Non-farm rural activities (NFRA) in a peasant economy: the case of the north Peruvian sierra. In: Proceedings of the 25th. International Conference of Agricultural Economists (IAAE). University of Manchester, Oxford

WFP (2017) Famine Early Warning Systems Network, Ethiopia Food Security Outlook Update, August 2017 report

Woldeamanuel S (2009) Poverty, food insecurity and livelihood strategies in rural Gedeo: the case of Haroressa and Chichu PAs, SNNP. ed. by Svein Ege, Harald Aspen, Birhanu Teferra and Shiferaw Bekele, Trondheim: Proceedings of the 16th international conference of Ethiopian studies

Wooldridge J (2002) Econometric analysis of cross section and panel data. MIT Press, Cambridge

Yamane T (1967) Statistics, an introductory analysis. $2^{\text {nd }}$ edition. Harper and Row Inc., New York, p 345

Yishak G, Gezahegn A, Tesfaye L, Dawit A, (2014) Rural household livelihood strategies: options and determinants in the case of Wolaita Zone, Southern Ethiopia. J Soc Sci 3(3): 92-104. https://doi.org/10.11648/j.ss.20140303.15

Zemedu L, Mesfin W (2014) Smallholders' vulnerability to food insecurity and coping strategies: in the face of climate change, east Hararghe, Ethiopia. J Econ Sustainable Dev 5(24):86-100

\section{Submit your manuscript to a SpringerOpen ${ }^{\circ}$ journal and benefit from:}

- Convenient online submission

- Rigorous peer review

- Open access: articles freely available online

- High visibility within the field

- Retaining the copyright to your article

Submit your next manuscript at $>$ springeropen.com 